\title{
Studi Evaluasi Pelaksanaan Pengajaran Alkitab di GPdI Haniel Sentani, Papua
}

\author{
Oral Oko*, Ferdie Denny Tuwo \\ Sekolah Tinggi Alkitab Jember, Jawa Timur \\ *oraloko@yahoo.com
}

\begin{abstract}
This research aims to find out the pastor's tendency as the executor of Bible teaching, as well as the aspects that shape it. How is the compatibility of the implementation of Bible teaching in GPdI Haniel Sentani Jayapura Papua with the pattern in the Bible. In this research, the analysis used is qualitative analysis. Data collection using a questionnaire, given to 100 participants. Based on the findings and analysis, most of the GPdI Haniel Sentani Papua congregations understand the shepherd's teaching patterns based on the Bible. In conclusion, the appropriateness of shepherd teaching is the same as the Bible pattern in GPdI Haniel Sentani Jayapura Papua. This can be proven by increasing church growth from year to year, both in quality and quantity. Congregations increasingly love God through loyalty and obedience in teaching.
\end{abstract}

Keywords: Bible; Bible teaching; church growth; GPdI

\begin{abstract}
Abstrak
Penelitian ini bertujuan untuk mengetahui kecendurungan gembala sidang sebagai pelaksana pengajaraan Alkitab, serta aspek-aspek yang membentuknya. Bagaimana kesesuaian pelaksanaan pengajaran Alkitab di GPdI Haniel Sentani Jayapura Papua dengan pola dalam Alkitab. Dalam penelitian ini, analisis yang digunakan adalah analisis kualitatif. Pengumpulan data mengunakan angket, kepada 100 partisipan. Berdasarkan hasil penemuan dan Analisa, sebagian besar jemaat GPdI Haniel Sentani Papua memahami tentang pola pengajaran gembala yang berdasarkan Alkitab. Kesimpulannya, bahwa kesesuaian pelaksanaan pengajaran gembala sama dengan pola Alkitab di GPdI Haniel Sentani Jayapura Papua. Hal ini dapat dibuktikan melalui perkembengan pertumbuhan gereja dari tahun ke tahun semakin bertambah, baik secara kualitas maupun secara kuantitas. Jemaat semakin mengasihi Tuhan melalui kesetiaan dan ketaatan dalam melakukan pengajaran.
\end{abstract}

Kata kunci: Alkitab; pengajaran Alkitab; GpdI; pertumbuhan gereja

\section{PENDAHULUAN}

Dalam pelaksaan pengajaran Alkitab kepada semua orang percaya, lebih khusus jemaat Gereja Pantekosta di Indonesia (GPdI) Haniel agar dapat berumbuh lebih pesat lagi, maka seorang gembala sidang harus mengadakan evaluasi. Patut disayangkan, dalam memimpin jemaat belum semua pelayanan, maksimal dalam pengajarkan Alkitab yang adalah Firman Allah tertulis. Hal itu nyata dari kehidupan jemaat yang ada di Gereja Pantekosta di 
Indonesia jemaat "Haniel” Sentani Jayapura Papua. Para pelayan jemaat seharusnya bisa melaksanakan pelayanan pengajaran sebab mereka mempunyai tugas untuk pengajar.

Menurut Doni Haryanto:

Gereja pada masa perjanjian Baru adalah persekutuan belajar mengajar. Pengajaran telah mandarah daging dalam kehidupan mereka (KPR 2:42). Pada masa berikutnya, Rasul Paulus juga melakukan pelayanan pengajaran (KPR 11:25-26). Ia mengajar secara pribadi dan mengajar melalui surat-suratnya. Setiap surat-suratnya adalah dokumen pengajaran yang berisi perintah-perinatah kepada mereka yang percaya karena pemberitaan Injil. Pada dasarnya surat-surat penggembalaan juga menunjukan bahwa gereja adalah komunitas belajar mengajar"1

Selaras dengan hal tersebut para pelayan jemaat di Gereja Pantekosta di Indonesia Sentani jayapura Papua sebaikknya lebih memberi perhatiaan pengajaran Alkitabnya, agar iman anak-anak Tuhan harus berdasar dan berakar dalam ajaran Kristus yang sudah ditulis dalam Alkitab.

Pertumbuhan jemaat secara kuantitas dapat terjadi karena beberapa faktor diantaranya faktor biologis penginjilan dan perpindahan jemaat. Sedangkan pertumbuhan jemaat dari segi kualitas dapat terjadi karena pengajaran oleh para rasul dalam kehidupan jemaat mulamula. hal ini diharapkan dapat diaplikasikan dalam pelayanan gereja GPdI Haniel Sentani papua. Sisi lain yang perlu mendapat perhatian dari para pelayan Gereja Pantekosta di Indonesia Haniel Sentani Papua dalam rangka penumbuhkan gereja adalah melibatkan seluruh jemaat dalam ibadah doa. Dengan adanya keterlibatan jemaat dalam doa dapat meningkatkan bertumbuhan jemaat.

Kegiatan doa yang dilaksanakan di gereja seperti: doa puasa, doa semalam suntuk, doa pagi, doa sore. Oleh karena itu hidup bertekun dalam doa perlu diterapkan dalam kehidupan jemaat yang ada saat ini. Gereja jangan merasa puas dengan banyak orang-orang yang dating ke gereja, karena jika gereja tidak membimbing jemaat kepada kesetiaan dating bersekutu dengan pencipta mereka melalui doa-doa yang benar dan dalam ketekunan, akan membuat gereja rapuh.

Menurut Peter Wongso:

Doa adalah senjata peperangan rohani, bukan hiasan agama belaka. Oleh sebab itu Paulus menyebut doa sebagai salah satu perlengkapan untuk perang rohani (Ef. 6:16). Tuhan sendiri memenangkan pergumulan yang paling dasyat melalui doa (Mat. 26:3646), yaitu doa di Getsemani dan doa di atas kaya salib (Mat. 27:46-50), sesaat sebelum menghembuskan nafas terakhir. ${ }^{2}$

Jemaat yang bertumbuh dalah jemaat yang memiliki kehidupan yang mengasihi sesama. Oleh karena itu hidup saling mengasihi perlu dibnagun secara maksimal bahkan perlu terus

${ }^{1}$ Doni Heryanto, Pendidikan Warga Gereja (Malang: STT Yestoya, 2008), 20.

${ }^{2}$ Peter Wongso, Theologi Penggembalan (Malang Seminar Alkitab Asia Tenggara, 1995), 6. 
di tingkatkan dalam kehidupan jemaat yang ada di Gereja Pantekosta di Indonesia Jemaat Haniel Sentani Jayarura Papua.

Keadaan umat Tuhan yang ada diakhir zaman akan menghadi banyak tantangan. Manusia akan semakin hari mementingkan diri sendiri, tidak mau peduli dengan orang yang ada disekeliling, hal tersebut perlu di waspadai oleh jemaat GPdI Haniel Sentani Papua. Seperti yang dikatakan Warren W Wiersbe, "Kasih terhadap Allah dan kasih terhadap sesama mendorong seseorang untuk mentaati perintah-perintah Allah secara spontan! Pada waktu seseorang menyatakan kasih Kristen, Ia taat kepada Allah dan melayani sesama, bukan karena takut tetapi karena kasihnya."3 Pengajaran Alkitab ini bukan hanya berlaku di masa para rasul, tetapi juga di gereja Tuhan masa kini, sehingga pola ini dapat diterapkan pada GPdI Haniel Sentani Papua. Dengan alasan inilah, maka penulis mengambil judul Tesis Studi Evaluasi Pelaksanaan Pengajaran Alkitab di GPdI Haniel Sentani Jayapura Papua”

\section{METODE PENELITIAN}

Metode penelitian yang dipergunakan dalam penelitian adalah rencana penelitian naturalis (kualitatif) dan deskripsif. Penelitian kualitatifi ini menekankan sifat yang bermuatan nilai dan mencari jawaban atas pertanyaan-pertanyaan yang menekankan bagaimana pengalaman social diciptakan dan diberi makna. ${ }^{4}$ Data-data penelitian diperoleh langsung dilapangan dengan menggunakan instrument penelitian berubah angket. Setiap pertanyaan ada dua pilihan jawaban. Selanjutnya data-data tersebut akan dijelaskan secara deskripsif untuk menjawab pertanyan-pertanyaan penelitian. Jadi pengelolahan data statistic hanya sebatas pada statistik deskriptif.

Metode pengumpulan data yang digunakan dalam penelitian ini adalah, metode penelitian lapangan dengan cara melakukan angket ke 100 jemaat GPdI Haniel Sentani Jayapura Papua dan dilaksanakan pada bulan juli 2013. Sebab peneliti berasumsi bahwa subjek penelitian merupakan orang-orang yang tahu tentang dirinya, dan pertanyaan subjek yang diberikan adalah benar dan dapat dipercaya. ${ }^{5}$ Dalam daftar angket tersebut, penelitian menggunakan daftar pertanyaan tentang pelaksanaan pengajaran alkitab di GPdI Haniel Sentani Papua, dengan pilihan jawaban Ya atau Tidak. Dengan harapan apabila partisipan merasa pertanyaan sesuai dengan keyakinannya, maka menjawab tidak.

Analisis data kualitatif erat hubungannya dengan pengumpulan data. Hasil penelitian dan pembahasan akan disajikan dalam bentuk deskripsi, analisis, dan interpretasi cara yang digunakan dalam pendiskripsian data tersebut adalah dilihat dari beberapa versi sudut

\footnotetext{
${ }^{3}$ Warren W. Wiersbe, Nyata dalam Kristus (Bandung: Kalam Hidup, 2003), 46.

${ }^{4}$ Ibid., 62.

${ }^{5}$ S. Nasution, Metode Research (Jakatra: Bumi Aksara, 2000),128.
} 
pandang orang. ${ }^{6}$ Deskripsi dalam penelitian ini menjadi usaha untuk mendapat jawaban tentang bagaimana "studi evaluasi pelaksanaan pengajaran Alkitab di GPdI Haniel Sentani Papua." Untuk memahami lebih lanjut mengenai hal tersebut diatas, maka secara berurutan hasil angket akan dideskripsikan dalam table-tabel sesuai variabelnya masing-masing yaitu:

I. Studi evaluasi pelaksanaan pengajaran Alkitab di GPdI Haniel Sentani Papua terdiri:

1. Pemahaman tentang pola pengajaran yang berdasarkan Alkitab.

2. Pemahaman tentang tujuan pengajaran Alkitab.

3. Pemahaman tentang pelaku pengajaran Alkitab

4. Pemahaman tentang meteri pengajaran Alkitab.

5. Pemahaman tentang metode pengajaran Alkitab.

II. Implementasi studi evaluasi pelaksanaan pengajaran Alkitab di GPdI Haniel Sentani Jayapura Papua terdiri dari:

1. Implementasi tentang pola pengajaran Alkitab

2. Implementasi tentang tujuan pengajaran Alkitab

3. Implementasi tentang pelaku pengajaran Alkitab

4. Implementasi tentang materi pengajaran Alkitab

5. Implementasi tentang metode pengajaran Alkitab

\section{HASIL DAN PEMBAHASAN}

Hasil penelitian disajikan dalam 10 tabel berikut ini:

Tabel 1: Pemahanan Jemaat Tentang Pola Pengajaran Gembala Berdasarkan Alkitab di GPdI Haniel Sentani Jayapura Papua

\begin{tabular}{|c|l|c|c|c|c|}
\hline No. & \multirow{2}{*}{ Item Pertanyaan } & \multicolumn{4}{|c|}{ Jumlah Jawaban } \\
\cline { 3 - 5 } & & Ya & Prosentase & Tidak & Prosentase \\
\hline 1. & $\begin{array}{l}\text { Pengajaran yang benar adalah pengajaran yang bersumber } \\
\text { dari Alkitab }\end{array}$ & 100 & $100 \%$ & 0 & $0 \%$ \\
\hline 2. & Yesus adalah satu-satunya pusat dari pengajaran Alkitab & 100 & $100 \%$ & 0 & $0 \%$ \\
\hline 3. & Alkitab adalah firman Allah yang tidak mungkin salah & 100 & $100 \%$ & 0 & $0 \%$ \\
\hline & Rata-rata & 100 & $100 \%$ & 0 & $0 \%$ \\
\hline
\end{tabular}

Berdasarkan tabel 1, maka dapat dijelaskan hasil penelitian sebagai berikut:

Pertama, dari pertanyaan no. 1 pada tabel di atas, partisipan menjawab Ya dari pertanyaan pengajaran yang benar adalah pengajaran yang bersumber dari Alkitab sebanyak 100 responden, yang diprosentasekan sebesar 100\%. Sedangkan yang menjawab tidak sebanyak 0 responden, yang diprosentasekan sebesar $0 \%$. Kedua, dari pertanyaan no. 2 pada table di atas, partisipan menjawab Ya dari pernyataan Yesus adalah satu-satunya

\footnotetext{
${ }^{6}$ Andreas B. Subagyo, Pengantar Riset Kuantitatif dan Kualitatif (Bandung: Kalam Hidup, 2004), 291.
} 
pusat dari pengajaran Alkitab, sebanyak 100 responden, yang diprosentasekan sebesar $100 \%$. Sedangkan yang menjawab tidak sebanyak 0 responden, yang diprosentasekan sebesar 0\%. Ketiga, dari pertanyaan no. 3 pada tabel di atas, partisipan menjawab Ya dari pernyataan Alkitab adalah Firman Allah yang tidak mungkin salah, sebanyak 100 responden yang diprosentasekan sebesar $100 \%$. Sedangkan yang menjawab tidak sebanyak 0 responden, yang diprosentasekan sebesar $0 \%$.

\section{Tabel 2: Pemahaman Jemaat Tentang Tujuan Pengajaran Alkitab dari Gembala di GPdI Haniel Sentani Jayapura Papua}

\begin{tabular}{|l|l|c|c|c|c|}
\hline \multirow{2}{*}{ No } & \multirow{2}{*}{ Item Pertanyaan } & \multicolumn{3}{|c|}{ Jumlah Jawaban } \\
\cline { 3 - 5 } & Ya & Prosentase & Tidak & Prosentase \\
\hline 1 & $\begin{array}{l}\text { Pengajaran Alkitab yang benar, akan } \\
\text { meningkatkan kualitas rohani jemaat }\end{array}$ & 100 & $100 \%$ & 0 & $0 \%$ \\
\hline 2 & $\begin{array}{l}\text { Dengan pengajaran Alkitab jemaat akan } \\
\text { semakin terdorong untuk } \\
\text { mengaplikasikan pengajaran Alkitab }\end{array}$ & 100 & $100 \%$ & 0 & $0 \%$ \\
\hline 3 & $\begin{array}{l}\text { Melalui pengajaran Alkitab, jemaat akan } \\
\text { semakin bertumbuh dalam iman serta } \\
\text { kasih kepada Tuhan dan sesama. }\end{array}$ & 100 & $100 \%$ & 0 & $0 \%$ \\
\hline & Rata-rata & 100 & $100 \%$ & 0 & $0 \%$ \\
\hline
\end{tabular}

Berdasarkan tabel no. 2 maka dapat dijelaskan hasil penelitian sebagai berikut:

Pertama, dari pertanyaan no. 1 pada tabel di atas, partisipan menjawab Ya dari pernyataan Pengajaran Alkitab yang benar, akan meningkatkan kualitas rohani jemaat sebanyak 100 responden yang diprosentasekan sebesar 100\%. Sedangkan yang menjawab tidak sebanyak 0 responden, yang diprosentasikan 0\%. Kedua, dari pertanyaan no. 2 pada tabel di atas, partisipan menjawab Ya dari pernyataan pengajaran Alkitab jemaat akan semakin terdorong untuk mengaplikasikan pengajaran Alkitab, sebanyak 100 responden, yang diprosentasekan sebesar 100\%. Sedangkan yang menjawab tidak sebanyak 0 responden, yang diprosentasekan sebesar 0\%. Ketiga, dari pertanyaan no. 3 pada tabel di atas, partisipan menjawab Ya dari pernyataan melalui pengajaran Alkitab, jemaat akan semakin bertumbuh dalam iman serta kasih kepada Tuhan dan sesama sebanyak 100 responden yang diprosentasekan sebesar 100\%. Sedangkan yang menjawab tidak sebanyak 0 responden, yang diprosentasekan sebesar $0 \%$.

\section{Tabel 3: Pemahaman Jemaat Tentang Pelaku Pengajaran Alkitab di GPdI Haniel Sentani Jayapura Papua}

\begin{tabular}{|l|l|l|c|c|c|}
\hline \multirow{2}{*}{ No } & \multirow{2}{*}{ Item Pertanyaan } & \multicolumn{4}{|c|}{ Jumlah Jawaban } \\
\cline { 3 - 6 } & Gembala adalah seorang pengajar/guru & 100 & $100 \%$ & 0 & $100 \%$ \\
\hline 1 & Gembala adalah seorang penginjil & 100 & $100 \%$ & 0 & $100 \%$ \\
\hline 2 & Gembala adalah seorang motivator & 100 & $100 \%$ & 0 & $100 \%$ \\
\hline 3 & Rata-rata & 100 & $100 \%$ & 0 & $100 \%$ \\
\hline
\end{tabular}


Berdasarkan tabel 3, maka dapat dijelaskan hasil penelitian sebagai berikut:

Pertama, dari pertanyaan no. 1 pada tabel di atas, partisipan menjawab Ya dari pernyataan gembala adalah seorang pengajar/guru, sebanyak 100 responden yang diprosentasekan sebesar $100 \%$. Sedangkan yang menjawab tidak sebanyak 0 responden, yang diprosenrtasekan sebesar $0 \%$. Kedua, dari pertanyaan no. 2 pada tabel di atas, partisipan menjawab Ya dari pernyataan gembala adalah seorang penginjil, sebanyak 100 responden yang diprosentasekan sebesar 100\%. Sedangkan yang menjawab tidak sebanyak 0 responden, yang diprosentasekan sebesar $0 \%$. Ketiga, dari pertanyaan no. 3 pada tabel di atas, partisipan menjawab Ya dari pernyataan gembala adalah seorang motivator, sebanyak 100 responden yang diprosentasekan sebesar 100\%. Sedangkan yang menjawab tidak sebanyak 0 responden, yang diprosentasekan sebesar $0 \%$.

\section{Tabel 4: Pemahaman Jemaat Tentang Materi Pengajaran Alkitab di GPdI Haniel Sentani Jayapura, Papua}

\begin{tabular}{|c|l|c|c|c|c|}
\hline \multirow{2}{*}{ No } & \multirow{2}{*}{ Item Pertanyaan } & \multicolumn{4}{|c|}{ Jumlah Jawaban } \\
\cline { 3 - 5 } & & Ya & Prosentase & Tidak & Prosentase \\
\hline 1 & Yesus adalah satu-satunya Juruselamat & 100 & $100 \%$ & 0 & $0 \%$ \\
\hline 2 & Manusia diselamatkan karena kasih karunia & 100 & $100 \%$ & 0 & $0 \%$ \\
\hline 3 & Yesus akan datang kembali pada kali yang kedua. & 100 & $100 \%$ & 0 & $0 \%$ \\
\hline & Rata-rata & 100 & $100 \%$ & 0 & $0 \%$ \\
\hline
\end{tabular}

Berdasarkan tabel 4, maka dapat dijelaskan hasil penelitian sebagai berikut:

Pertama, dari pertanyaan no.1 pada tabel di atas, partisipan menjawab Ya dari pernyataan Yesus adalah satu-satunya Juruselamat, sebanyak 100 responden yang diprosentasekan sebesar $100 \%$. Sedangkan yang menjawab tidak sebanyak 0 responden, yang diprosentasekan sebesar 0\%. Kedua, dari pertanyaan no.2 pada tabel di atas, partisipan menjawab Ya dari pernyataan manusia diselamatkan karena kasih karunia sebanyak 100 responden yang diprosentasekan sebesar $100 \%$. Sedangkan yang menjawab tidak sebanyak 0 responden, yang diprosentasekan sebesar 0\%. Ketiga, dari pertanyaan no.3 tabel d iatas, partisipan menjawab Ya dari pernyataan Yesus akan datang kembali pada kali yang kedua, sebanyak 100 responden yang diprosentasekan sebesar 100\%. Sedangkan yang menjawab tidak sebanyak 0 responden, yang diprosentasekan sebesar $0 \%$.

\section{Tabel 5: Pemahaman Jemaat Tentang Metode Pengajaran Alkitab} di GPdI Haniel Sentani Jayapura, Papua

\begin{tabular}{|l|l|c|c|c|c|}
\hline \multirow{2}{*}{ No } & \multirow{2}{*}{ Item Pertanyaan } & \multicolumn{4}{|c|}{ Jumlah Jawaban } \\
\cline { 3 - 5 } & & Ya & Prosentase & Tidak & Prosentase \\
\hline 1 & Alkitab dapat diajarkan dengan cara berkhotbah & 100 & $100 \%$ & 0 & $0 \%$ \\
\hline 2 & Alkitab dapat diajarkan dengan cara tanya jawab & 100 & $100 \%$ & 0 & $0 \%$ \\
\hline 3 & Alkitab dapat diajarkan dengan cara berdiskusi & 100 & $100 \%$ & 0 & $0 \%$ \\
\hline & Rata-rata & 100 & $100 \%$ & 0 & $0 \%$ \\
\hline
\end{tabular}


Berdasarkan tabel 5 maka dapat dijelaskan hasil penelitian sebagai berikut:

Pertama, dari pertanyaan no.1 tabel di atas, partisipan menjawab Ya dari pernyataan Alkitab dapat diajarkan dengan cara berkhotbah, sebanyak 100 responden yang diprosentasekan sebesar $100 \%$. Sedangkan yang menjawab tidak sebanyak 0 responden, yang diprosentasekan sebesar 0\%. Kedua, dari pertanyaan no.2 tabel di atas, partisipan menjawab Ya dari pernytaan Alkitab dapat diajarkan dengan cara tanya jawab sebanyak 100 responden yang diprosentasekan sebesar 100\%. Sedangkan yang menjawab tidak sebanyak 0 responden, yang diprosentasekan sebesar 0\%. Ketiga, dari pertanyaan no.2 tabel di atas, partisipan menjawab Ya dari pernyataan Alkitab dapat diajarkan dengan cara berdiskusi sebanyak 100 responden yang diprosentasekan sebesar 100\%. Sedangkan yang menjawab tidak sebanyak 0 responden, yang diprosentasekan sebesar $0 \%$.

\section{Tabel 6: Implementasikan tentang Pelaksanaan Pengajaran Alkitab} di GPdI Haniel Sentani, Papua

\begin{tabular}{|c|l|l|c|c|c|}
\hline \multirow{2}{*}{ No } & \multirow{2}{*}{ Item Pertanyaan } & \multicolumn{3}{|l|}{ Jumlah Jawaban } \\
\cline { 3 - 6 } & & Ya & Prosentase & Tidak & Prosentase \\
\hline 1 & Pusat pengajaran gembala hanya bersumber dari Alkitab & 100 & $100 \%$ & 0 & $0 \%$ \\
\hline 2 & Pusat dari pemberitaan gembala sidang adalah Tuhan Yesus & 100 & $100 \%$ & 0 & $0 \%$ \\
\hline 3 & $\begin{array}{l}\text { Alkitab adalah pedoman kehidupan jemaat yang diajarkan } \\
\text { oleh gembala }\end{array}$ & 100 & $100 \%$ & 0 & $0 \%$ \\
\hline & Rata-rata & 100 & $100 \%$ & 0 & $0 \%$ \\
\hline
\end{tabular}

Berdasarkan tabel 6, maka dapat dijelaskan hasil penelitian sebagai berikut:

Pertama, dari pertanyaan no.1 pada tabel d iatas, pertisipan menjawab Ya dari pertanyaan pusat pengajaran gembala hanya bersumber dari Alkitab sebanyak 100 responden yang diprosentasikan sebesar $100 \%$. Sedangkan yang menjawab Tidak sebanyak 0 responden, yang diprosentasikan sebanyak 0\%. Kedua, dari pertanyaan no. 2 pada tabel di atas, partisipan menjawab Ya dari pernyataan pusat dari pemberitan gembala sidang adalah Tuhan Yesus, sebanyak 100 responden yang diprosentasekan sebesar 100\%. Sedangkan yang menjawab Tidak sebanyak 0 responden, yang diprosentasekan sebesar $0 \%$. Ketiga, dari pertanyaan no.3 pada tabel di atas partisiapan menjawan Ya dari pernyataan Alkitab adalah pedoman kehidupan jemaat yang diajarkan oleh gembala sebanyak 100 responden yang diprosentasekan sebesar 100\%. Sedangkan yang menjawab Tidak sebanyak 0 responden, yang di prosentasekan sebesar $0 \%$. 


\section{Tabel 7: Implementasi tentang tujuan pengajaran Alkitab di GPdI Haniel Sentani Jayapura, Papua}

\begin{tabular}{|c|l|c|c|c|c|}
\hline \multirow{2}{*}{ No } & Item Pertanyaan & \multicolumn{3}{|c|}{ Jumlah Jawaban } \\
\cline { 2 - 5 } & Ya & Prosentase & Tidak & Prosentase \\
\hline 1 & $\begin{array}{l}\text { Kualitas kerohanian jemaat bertumbuh, melalui pengajaran gembala } \\
\text { yang Alkitabiah. }\end{array}$ & 100 & $100 \%$ & 0 & $0 \%$ \\
\hline 2 & $\begin{array}{l}\text { Jemaat terdorong untuk menerapkan firman Allah dari pengajaran } \\
\text { Alkitab yang diajarkan genbala }\end{array}$ & 100 & $100 \%$ & 0 & $0 \%$ \\
\hline 3 & $\begin{array}{l}\text { Pengajaran Alkitab yang diajarkan gembala memotivasi jemaat } \\
\text { untuk semakin mengasihi Tuhan dan sesama. }\end{array}$ & 100 & $100 \%$ & 0 & $0 \%$ \\
\hline & Rata-rata & 100 & $100 \%$ & 0 & $0 \%$ \\
\hline
\end{tabular}

Berdasarkan tabel 7, maka dapat dijelaskan hasil penelitian sebagai berikut:

Pertama, dari pertanyaan no. 1 pada tabel di atas, partisipan menjawab Ya dari pernyataan kualitas kerohanian jemaat bertumbuh, melalui pengajaran gembala yang alkitabiah, sebanyak 100 responden yang diprosentasekan sebesar 100\%. Sedangkan yang menjawab tidak sebanyak 0 responden, yang diprosentasekan sebesar $0 \%$. Kedua, dari pertanyaan no. 2 pada tabel di atas, partisipan menjawab Ya dari pernyataan jemaat terdorong untuk menerapkan firman Allah dari pengajaran Alkitab yang diajarkan gembala, sebanyak 100 responden yang diprosentasekan sebesar 100\%. Sedangkan yang menjawab tidak sebanyak 0 responden, yang diprosentasekan sebesar $0 \%$. Ketiga, dari pertanyaan no. 3 pada tabel di atas, partisipan menjawab Ya dari pernyataan pengajaran Alkitab yang diajarkan gembala memotivasi jemaat untuk semakin mengasihi Tuhan dan sesame, sebanyak 100 responden yang diprosentasekan sebesar 100\%. Sedangkan yang menjawab tidak sebanyak 0 responden, yang diprosentasekan sebesar $0 \%$.

\section{Tabel 8: Implementasi pelaku pengajaran Alkitab di GPdI Haniel Sentani, Jayapura Papua}

\begin{tabular}{|c|c|c|c|c|}
\hline \multirow{2}{*}{ NoItem Pertanyaan } & \multicolumn{4}{|c|}{ Jumlah Jawaban } \\
\hline & $\mathrm{Ya}$ & Prosentase & Tidak & Prosentase \\
\hline 1. Ketika gembala berkhotbh, di dalamnya ada pengajaran Alkitab. & 100 & $100 \%$ & 0 & $0 \%$ \\
\hline 2. Ketika gembala berkhotbh, di dalamnya ada penginjilan. & 100 & $100 \%$ & 0 & $0 \%$ \\
\hline $\begin{array}{l}\text { 3. Ketika jemaat menghadapi masalah, gembala hadir sebagai } \\
\text { seorang motivator. }\end{array}$ & 100 & $100 \%$ & 0 & $0 \%$ \\
\hline Rata-rata & 100 & $100 \%$ & 0 & $0 \%$ \\
\hline
\end{tabular}

Berdasarkan tabel 8, maka dapat dijelaskan hasil penelitian sebagai berikut:

Pertama, dari pertanyaan no. 1 pada tabel di atas, partisipan menjawab Ya dari pernyataan ketika gembala berkhotbh, di dalamnya ada pengajaran Alkitab sebanyak 100 responden yang diprosentasekan sebesar $100 \%$. Sedangkan yang menjawab tidak sebanyak 0 responden, yang diprosentasekan sebesar 0\%. Kedua, dari pertanyaan no. 2 pada tabel di atas, partisipan menjawab Ya dari pernyataan ketika gembala berkhotbh, di dalamnya ada 
penginjilan, sebanyak 100 responden yang diprosentasekan sebesar 100\%. Sedangkan yang menjawab tidak sebanyak 0 responden, yang diprosentasekan sebesar 0\%. Ketiga, dari pertanyaan no. 3 pada tabel di atas, partisipan menjawab Ya dari pernyataan ketika jemaat menghadapi masalah, gembala hadir sebagai seorang motivator, sebanyak 100 responden yang diprosentasekan sebesar $100 \%$. Sedangkan yang menjawab tidak sebanyak 0 responden, yang diprosentasekan sebesar $0 \%$.

\section{Tabel 9: Implementasi Tentang Materi Pengajaran Alkitab di GPdI Haniel Sentani Jayapura Papua}

\begin{tabular}{|c|l|c|c|c|c|}
\hline \multirow{2}{*}{ No } & Item Pertanyaan & \multicolumn{3}{|c|}{ Jumlah Jawaban } \\
\cline { 2 - 5 } & Ya & Prosentase & Tidak & Prosentase \\
\hline 1. & $\begin{array}{l}\text { Gembala mengajarkan kepada jemaat bahwa Yesus adalah } \\
\text { satu-satunya Juruselamat. }\end{array}$ & 100 & $100 \%$ & 0 & $0 \%$ \\
\hline 2. & Gembala mengajarkan tentang kasih karunia Allah bagi jemaat. & 100 & $100 \%$ & 0 & $0 \%$ \\
\hline 3. & $\begin{array}{l}\text { Gembala mempersiapkan jemaat untuk menyambut kedatangan } \\
\text { Yesus yang kedua kali. }\end{array}$ & 100 & $100 \%$ & 0 & $0 \%$ \\
\hline & \begin{tabular}{l} 
Rata-rata \\
\cline { 2 - 5 }
\end{tabular} & 100 & $100 \%$ & 0 & $0 \%$ \\
\hline
\end{tabular}

Berdasarkan table 9, maka dapat dijelaskan hasil penelitian sebagai berikut:

Pertama, dari pertanyaan no. 1 partisipan menjawab Ya dari pernyataan gembala mengajarkan kepada jemaat bahwa Yesus adalah satu-satunya Juruselamat, sebanyak 100 responden yang diprosentasekan sebesar $100 \%$. Sedangkan yang menjawab tidak sebanyak 0 responden, yang diprosentasekan sebesar $0 \%$. Kedua, dari pertanyaan no. 2 pada tabel di atas, partisipan menjawab Ya dari pernyataan gembala mengajarkan tentang kasih karunia Allah bagi jemaat, sebanyak 100 responden yang diprosentasekan sebesar $100 \%$. Sedangkan yang menjawab tidak sebanyak 0 responden, yang diprosentasekan sebesar $0 \%$. Ketiga, dari pertanyaan no. 3 pada tabel di atas, partisipan menjawab Ya dari pernyataan gembala mempersiapkan jemaat untuk menyambut kedatangan Yesus yang kedua kali, sebanyak 100 responden yang diprosentasekan sebesar 100\%. Sedangkan yang menjawab tidak sebanyak 0 responden, yang diprosentasekan sebesar $0 \%$.

Tabel 10: Implementasi Metode Pengajaran Alkitab di GPdI Haniel Sentani Papua

\begin{tabular}{|l|l|c|c|c|c|}
\hline \multirow{2}{*}{ No } & \multicolumn{1}{|c|}{ Item Pertanyaan } & \multicolumn{3}{|c|}{ Jumlah Jawaban } \\
\cline { 3 - 6 } 1. & Gembala memberi pengajaran Alkitab kepada jemaat melalui khotbah & 100 & $100 \%$ & 0 & $0 \%$ \\
\hline 2. & Gembala melibatkan jemaat melalui proses Tanya jawab Alkitab. & 100 & $100 \%$ & 0 & $0 \%$ \\
\hline 3. & $\begin{array}{l}\text { Gembala memberikan kesempatan bagi jemaat untuk mendiskusikan } \\
\text { pengajaran yang diajarkan. }\end{array}$ & 100 & $100 \%$ & 0 & $0 \%$ \\
\hline & Rata-rata & 100 & $100 \%$ & 0 & $0 \%$ \\
\hline
\end{tabular}


Berdasarkan tabel 10, Maka dapat dijelaskan hasil penelitian sebagai berikut:

Pertama, dari pertanyaan no. 1 pada tabel di atas, partisipan menjawab Ya dari pernyataan gembala memberi pengajaran Alkitab kepada jemaat dengan berkhotbah, sebanyak 100 responden yang diprosentasekan sebesar 100\%. Sedangkan yang menjawab tidak sebanyak 0 responden, yang diprosentasekan sebesar $0 \%$. Kedua, dari pertanyaan no. 2 pada tabel di atas, partisipan menjawab Ya dari pernyataan gembala melibatkan jemaat melalui proses Tanya jawab Alkitab, sebanyak 100 responden yang diprosentasekan sebesar $100 \%$. Sedangkan yang menjawab tidak sebanyak 0 responden, yang diprosentasekan sebesar $0 \%$. Ketiga, dari pertanyaan no. 3 pada tabel di atas, partisipan menjawab Ya dari pernyataan gembala mempersiapkan jemaat untuk menyambut kedatangan Yesus yang kedua kali, sebanyak 100 responden yang diprosentasekan sebesar 100\%. Sedangkan yang menjawab tidak sebanyak 0 responden, yang diprosentasekan sebesar $0 \%$.

\section{Analisis Data}

Berdasarkan hasil temuan dan analisis data pada table 1 di atas maka dapat digambarkan bahwa sebagian jemaat GPdI Haniel Sentani Papua memahami tentang Pola pengajaran gembala yang berdasarkan Alkitab. Kecenderungan gembela untuk tetap menerapkan pola pengajaran yang berdasarkan Alkitab, sangat mendapatkan perhatian dari sebagian besar sidang jemaat. Pola pengajaran Alkitab di GPdI Haniel, memberi pemahaman firman Tuhan yang baik dari pada apa yang diajarkan oleh gembala sidang jemaat, sehingga memberi dampak yang sangat positif bagi pertumbuhan rohani jemaat Haniel Sentani Papua.

Dari hasil jawaban pada tabel 2 dapat diketahui bahwa dari semua partisipan menunjukkan bahwa pemahaman partisipan akan tujuan pengajaran Alkitab, memberi manfaat yang besar dalam pertumbuhan jemat. Jemaat menyadari betapa penting pengajaran Alkitab yang harus diikuti sepenuh hati kerena dengan pengajaran Alkitab yang benar, dapat meningkatkan kualitas rohani jemaat. Jemaat semakin bertumbuh didalam mengasihi Tuhan dan sesama. Juga mengetahui keselamatan kekal yang hanya bisa

diperoleh lewat kasih dan anugrah Allah didalam pengorbanan Tuhan Yesus Kristis sang juru selamat manusia.

Dari hasil jawaban tabel 3 yang di dapat bahwa semua pelayan jemaat terutama gembala sidang dalam jemaat local yang adalah sebagai pelaku utama pengajaran Alkitab, sangat memberikan kontrubusi yang besar dalam membangun atau menggembangkan pelayanan pekerjaan Tuhan GPdI Haniel Sentani jayapura Papua. Tanggung jawab seorang pelayan apalagi gembela sidang jemaat sebagai pelaku pengajaran Alkitab kepada yang Empunya pekerjaan, dapat dilihat hasil pelayanan dengan melahirkan pelaku-pelaku pengajaran Alkitab, dalam hal ini terutama adalah gembala-gembala sidang yang baru, 
penulis menyaksikan langsung beberapa anggota sidang jemaat GPdI Haniel Sentani Jayapura Papua menyerahkan diri untuk menjadi pelaku pengajaran Alkitab dan mengikuti Sekolah Alkitab (SA) kemudian menjadi gembala jemaat sendiri. Sebagaimana amanat dari Tuhan Yesus Kristus sebelum naik ke surga dalam Matius 28:19-20 "karena itu pergilah, jadikanlah semua bangsa muridku dan baptislah mereka dalam nama Bapa dan Anak dan Roh Kudus, dan ajarlah mereka melakukan segala sesuatu yang telah kuperintahkan kepadamu. Dan ketahuilah, Aku menyertai engkau senantiasa sampai pada akhir zaman." Dari dua kata yang menonjol yang dikatakan oleh Tuhan Yesus kepada semua murid-nya pada waktu itu untuk dilaksanakan adalah ajarlah dan melakukan.

Pada waktu gembala sidang dengan tekun mengajar sekaligus untuk melakukan perintah-perintah firman Tuhan, jadi baik mengajar maupun yang diajar atau baik gembala sidang maupun jemaat Tuhan sama-sama untuk menjadi pelaku firman Tuhan dengan setia, sudah pasti akan menjadi Gerakan pertumbuhan yang baik sesuai kehendak Tuhan. Seperti yang dialami oleh jemaat GPdI Haniel Sentani Jayapura Papua. Walaupun dirasa belumlah maksimal, akan tetapin dapat dilihat perkembangan pelayanan pekerjaan Tuhan dengan bertambahnya jiwa-jiwa baru atau petobat-petobat baru yang dilayani, juga dengan mengirim utusan-utusan untuk membuka ladang-ladang baru sebagai gembala sidang mandiri, sudah menunjukkan bahwa sidang jemaat GPdI Haniel Sentani Jayapura Papua mulai dari gembala sampai kepada jemaat adalah dapat mengajar atau melakukan pengajaran seperti apa yang di amanatkan oleh Tuhan Yesus Kristus.

Menjadi pelaku pengajaran tidaklah mudah selain harus memahami panggilan dari Tuhan seorang sebagai guru atau pengajar, juga harus melengkapi diri dengan pengetahuanpengetahuan teologis yang Alkitabiah dan pengetahuan umum atau secular. Dengan demikian sebagai pelaku pengajar, harus mengikuti Pendidikan-pendidikan terutama Teologi, sehingga dapat menjawab segala tantangan-tangangan yang semakin kompleks di zaman modern sekarang ini.

Dari tabel 4 seratus orang jemaat memahami semua materi pengajaran Alkitab. Akan tetapi semua orang percaya pasti tahu bahwa Tuhan Yesus adalah Allah yang maha kuasa ada disegala tempat, desegala waktu, disegala keadaan situasi apapun. Dapat dikatakan bahwa Tuhan Yesus adalah pusat materi pengajaran Alkitab bagi manusia. Dalam meningkatkan pemahaman Alkitab secara menyeluruh dibuat materi pelajaran Alkitab dalam bentuk bergambar diatas kain spanduk dengan besar 4 meter tinggi dan 8 meter Panjang dengan judul,"Rencana keselamatan Allah dalam Kristus Yesus dari kekal sampai kekal" ada dibuat oleh gembala pertama GPdI Haniel Sentani Jayapura dan terus diajarkan kepada jemaat disetiap waktu dan kesempatan penginjilan kedalam dan keluar jemaat. Dan akibat pengajaran-pengajaran yang benar, banyak orang datang menerima Yesus sebagai Tuhan dan Juruselamat mereka. 
Setelah semua angket dikumpulkan maka dapat dilihat dari tabel 5 menunjukkan metode pengajaran yang diterapkan oleh gembala sidang jemaat GPdI Haniel Sentani Jayapura Papua, dapat meningkatkan kerohanian oleh karena metode-metode pengajaran yang menarik juga mudah untuk dimengerti atau dipahami.

Dari hasil jawaban partisipan 6 yang semuanya menjawab Ya pada tabel di atas maka peneliti dapat mengevaluasi pelaksanaan pengajaran Alkkitab di GPdI jemaat Haniel, menunjukkan peningkatan kualitas kerohanian dan pengetahuan akan kebenaran firman Tuhan dari jemaat yang dilayani cukup baik. Untukm itu pelaksanaan pengajaran Alkitan dijemaat, harus terus sitingkatkan sehingga jemaat makin memahami dengan baik semua pengajaran Alkitab yang diberikan dan terus menjadi pelaku kebenaran firman yang setia.

Dari hasil jawaban pada tabel 7 dapat diketahui bahwa semua partisipan menjawab Ya dari tiga pertanyaan dalam tabel di atas. Dapatlah dipahami bahwa tujuan pengajaran Alkitab di GPdI Haniel Sentani, dapat tercapai dengan baik dan harus terus dipertahankan dan dan kalua bisa ditingkatkan. Sudah barang tentu untuk mencapai tujuan pengajaran Alkitab yang dikehendaki oleh Tuhan yang Empunya jiwa-jiwa dirasa masih jauh dari sempurna, itulah sebabnya perlu terus ditingkatkan dengan bekerja lebih giat lagi dan juga terus diupayakan terobosan-terobosan yang barudengan tidak keluar dari jalur kebenaran firman Tuhan.

Dari jawaban yang diberikan oleh setiap patisipan pada table 8 , menurut peneliti hal seperti inilah yang membuat pengajaran Alkkitab dalam satu bidang jemaat bisa mencapai tujuan dengan baik. Bagaimana pelaku pengajaran Alkitab bisa membawa dirinya untuk menjadi contoh dan teladan dalam semua aspek kehidupan juga bagaimana sebagai pelaku pengajaran mempersiapkan dirinya dengan memiliki banyak pengetahuan-pengetahuan teologis juga umum atau secular, dan memiliki wawasan yang liuas, dan paling penting sudah penuh dengan Roh Kudus. Maka sudah pasti kredibilitasnya sebagai pelaku pengajaran Alkitab, tidak diragukan lagi. Untuk itu sebagai pelaku pengajaran Alkitab artinya mewakili Tuhan dalam penyampaian setiap maksud-maksud Tuhan kepada semua umatnya, harus hidup tidak bercelah dihadapan manusia terlebih dihadapan Tuhan yang empunya hidup ini. Pelaku pengajaran Alkitab juga memiliki karakter kristus dalam semua aspek kehidupannya, sehingga semua ajaran yang disampaikannya, mendapat tempat sihati semua umat Tuhan.

Berdasarkan table 9, materi pengajaran diberikan bervariasi menunjukkan bahwa metari pengajaran yang du terima, memberi manfaat yang besar bagi pertumbuhan iman atau rohani jemaat Tuhan di GPdI Haniel Sentani Jayapura Papua.

Berdasarkan table 10 semuanya memberikan jawaban Ya pada lembaran angket, menunjukkan bahwa metode pengajaran Alkitab yang dilakukan di GPdI Haniel, dapat dikatakan memberi hasil yang baik. Metode baik dan benar akan memudahkan semua 
jemaat memahami kebenatran yang hakiki dari setiap pengajaran firman yang diberikan. Itu sebabnya memakai metode yang baik dan benar perlu terus dipertahankan bahkan harus terus ditingkatkan, sehingga memiliki jemaat yang Tangguh menghadapi situasi apapun didalam dunia ini. Penggunaan metode juga harus dilihat dengan jeli, itu bergantung pada situasi dan kondisi tempat dimana pelaku pengajaran Alkitab sedang melaksanakan tugasnya sebagai pengajar. Penting sekali untuk memintah hikmat kepada Tuhan agar apapun metode yang dilakukan, tidaklah menjadi sia-sia.

\section{KESIMPULAN}

Jemaat di GPdI Haniel Sentani Jayapura Papua telah memiliki pemahaman tentang pelaksanaan pengajaran Alkitab, hal ini terlihat dari: Kesesuaian pelaksanaan pengajaran gembala sama dengan pola Alkitab di GPdI Jemaat Haniel Sentani Jayapura Papua; pelaksanaan pengajaran Alkitab mulai dari perjanijian lama sampai kepada perjanjian baru diinplementasikan di GPdI jemaat Haniel Sentani Jayapura Papua; menjadikan jemaat yang militan, jemaat yang Bersatu, jemaat yang mulia adalah tujuan pelaksanaan pengajaran Alkitab di GPdI jemaat Haniel Sentani Jayapura Papua; guru apalagi gembala sidang jemaat adalah sebagai pelaku pengajaran Alkitab di GPdI jemaat Haniel Sentani Jayapura Papua; materi pengajaran utama selalu diambil dari Alkitab dan diajarkan kepada GPdI Jemaat Haniel Sentani Jayapura Papua. Sedangkan metode pengajaran utama gembala dilakukan melalui khotbah, kuliah, seminar atau ceramah, dan tanya jawab di GPdI Jemaat Haniel Sentani Jayapura Papua.

\section{REFERENSI}

Abineno, J.L.CH. Sekitar Katekese Gerejawi. Jakarta: BPK Gunung Mulia, 1997.

Anthony, Michael J. Foundations Ministry an Introduction to Christian Education for a New Generation. Malang: Gandum Mas, 2010.

Barney, Kenenth D. Surat Efesus, Doktrin Keselamatan. Malang: Seminari Alkitab Asia Tenggara, 1993.

Becker, Theol Diater. Pedoman Dogmatika. Jakarta: BPK Gunung Mulia, 1996.

Brill, J. Wesley. Dasar yang teguh. Bandung: Kalam Hidup, 1997.

Carson, DA. Gereja Zaman Perjanjian Baru dan Masa Kini. Malang: Gandum Mas, 1997.

Conner, Kevin J. Jemaat Dalam Perjanjian Baru. Malang: Gandum Mas, 2004.

Departemen Pendidikan Nasional. Kamus Besar Bahasa Indonesia Pusat Bahasa Edisi

Keempat. Jakarta: PT Gramedia Pustaka Utama, 2008.

Dister, Niko Syukur. Pengantar Teologi. Jakarta: BPK Gunung Mulia, 1992.

Domazio, Frank. Memimpin dengan Roh. Yogyakarta: ANDI, 2004.

Gangel, Kenneth O. Membina Pemimpin Pendidikan Kristen. Malang: Gandum Mas, 1998. Gozali, Mohammad Al. Christ, Muhammad and I. Ontario: Calif CHICK Publications, tt. Graham, Billy. Berita Injil. Bandung: Literatur Baptis, 1992.

Heryanto, Doni. Pendidikan Warga Gereja. Malang: STT YESTOYA, 2008. 
Hulu, Yuprieli, Alfrida L. P. Bertumbuh dalam Kristus. Jakarta: BPK Gunung Mulia, 2007.

Homrighausen, Enklaar. Pendidikan Agama Kristen. Jakarta: BPK Gunung Mulia, 2008.

Indra, Igwei G. Teologia Sistematika. Bandung: Literatur Baptis, 1999.

Ingouf, Jhon E. Sekelumit tentang Gembala Sidang. Bandung: Literatur Baptis, 1992.

Ismail, Andar. Ajarlah Mereka Melakukan, Jakarta: BPK Gunung Mulia, 2006.

Jang, S. de. Khotbah: Persiapan - Isi - Bentuk. Jakarta: BPK Gunung Mulia, 2006.

KBBI Departemen Pendidikan Nasional. Jakarta: Balai Pustaka, 2008.

Lapian, L. Lima Jawatan dalam Gereja. Manado: Biro Penginjilan, 1995.

Akhir zaman, Alkitab, Malaikat, Sorga dan Neraka, Manusia dan Dosa. Pare:

Departemen Pendidikan dan Pengajaran Majelis Pusat dan GPdI, 2005.

Leigh, Ronald W. Melayani dengan Efektif. Jakarta: BPK. Gunung Mulia, 1996.

Leon, Xavier. Ensiklopedi Perjanjian Baru, Yogyakarta: Penerbit Kanisius, 1993.

Lilik, Kristianto Paulus. Prinsip dan Praktik Pendidikan Kristen. Yogyakarta: ANDI, 2006.

Nasution S. Metode Research. Jakarta: Bumi Aksara, 2000.

Oentoro, Jimmy. Live Full Lives, Komentar Kitab Efesus. Jakarta: Harvest Publication House, $\mathrm{tt}$.

Packer, J. I., Ferguson, Sincklair B. dan Wright, David F. New Dictionary of Theologi, Jilid 2. Malang: Literatur SAAT, 2009.

Price, Frederick K. C. Saran-saran Praktis Untuk Pelayanan yang Berhasil. Jakarta: Immanuel, 1993.

Sasmoko E. Metode Penelitian dan Analisis Data. Lippo Karawaci Tanggerang: HITS, 2005.

Sekolah Kristen IPEKA. The Power For True Succes, Kuasa Untuk Mencapai Keberhasilan Sejati. Illinois: Basic Life Principles, 2005.

Sijabat, BS. Menjadi Guru Profesional. Bandung: Kalam Hidup, 2009.

Sosipater, Karel. Etika Perjanjian Baru. Jakarta: Suara Harapan Bangsa, 2010.

Sualang, Fahrenheit. Pendidikan Rohani yang Berhasil. tp, tt, 2002.

Subagyo, Andreas B. Pengantar Riset Kuantitatif dan Kualitatif. Bandung: Kalam Hidup, 2004.

Suryabrata, Sumadi. Metodologi Penilitian. Jakarta: Grafindo Persada, 1998.

Stott, Jhon R. W. Karunia-karunia. Jakarta: Yayasan Komunikasi Bina Kasih, 2003.

Stott, John. Isu-isu Global. Jakarta: Yayasan Komunikasi Bina Kasih, 1996.

Tenney, Merrill C. Survei Perjanjian Baru. Malang: Gandum Mas, 1992.

Werren, Rick. The Purpose Driven Church. Malang: Gandum Mas, 2012.

Pertumbuhan Gereja Masa Kini. Malang: Gandum Mas, 2012.

Wiersbe, Warren W. Nyata Dalam Kristus. Bandung: Kalam Hidup, 2003.

Willis, Wesley R. Make Your Teaching Count. Illinois: Victor Books, 1986.

Wongso, Peter. Soteriologi, Doktrin Keselamatan. Malang: Seminari Alkitab Asia

Tenggara, 1993.

Theologi Penggembalaan. Malang: Seminar Alkitab Asia Tenggara, 1995.

Ralph Mahoney, Lima Karunia Kepemimpinan, www.lead.sabda.org, 8 Nopember 2005. 